\title{
Surprise ecologies: case studies on temporal vulnerability in four North American floodplains
}

\author{
Daniel H. de Vries $^{1}$
}

\begin{abstract}
When hazards, such as floods, are collectively experienced as "surprising", this heightens the shock experience and likelihood of disaster, and exacerbates its impact. I outline how such collective surprises can be seen as the outcome of a dynamic condition of vulnerability that revolves around how humans construct expectations about future risks. This "temporal vulnerability" is determined largely by the experience of dynamic processes through time, or temporality. This paper is based on ethnohistorical data collection in four U.S. floodplains (California, Louisiana, North Carolina, Georgia) from 2000 through 2005. It shows how surprise conditions can be studied by focusing on temporal referentiality, or how successfully evaluators bring lived experience and historical data into the present. Results showed that temporal vulnerability increases as a result of the "narrowing" of relatively predictable surprise conditions in three interactive, dynamic systems: human meaning making, landscape change, and stochastic timing of hazard events. Conditions of surprise are classified by lack of temporal references (ignorance), erosion of temporal referencing practices (naivety), and misguided temporal referencing (denial). The concept of temporal resilience is outlined and illustrated.
\end{abstract}

Key Words: expectations; flooding; memory; referentiality; resilience; surprise; temporality; vulnerability

\section{INTRODUCTION}

\section{Surprise in social-ecological theory}

While studying episodes of discontinuous change in natural ecosystems in the 1980s, the ecologist C.S. Holling defined the concept of ecological surprise as "occurring when causes turn out to be sharply different than was conceived, when behaviors are profoundly unexpected, and when action produces a result opposite to that intended - in short, when perceived reality departs qualitatively from expectations" (Holling 1986:294). He emphasized that ecological surprises concerned both the natural system and the people "who seek to understand causes, to expect behaviors, and to achieve some defined purpose by action" (Holling 1986:294). Later, he worked out a "theory of surprise", where he detailed cultural worldviews about the interaction between people and environments that lead to radically different expectations and potential surprise trajectories (Holling 1995).

Holling's macrotheory on ecological surprise and his emphasis on human cultural expectations has remained inspiring to researchers in the field of resilience thinking (Walker and Salt 2006). The concept has featured centrally in discussions of the adaptive challenges that occur after complex systems suddenly "flip" from one organizational state into another as a result of difficult-to-predict- "surprising"- -synergies, nonlinearities, and cross-scale interactions (Holling 1973, Holling and Gunderson 2002, Folke et al. 2004, McDaniel and Driebe 2005, Gunderson 2010). For example, Biggs et al. write, “...ecological regime shifts are notoriously difficult to predict. Most regime shifts come as surprises, and the conditions and mechanisms leading to them only become clear once the shift has occurred" (Biggs et al. 2009:826). Influenced by constructivist risk theorists such as Douglas and Thompson (Douglas and Wildavsky 1983, Thompson et al. 1990), Holling emphasizes the relevance of cultural worldviews, human perceptions of reality, and expectations. Yet in most other commentaries on the subject, any emphasis on surprise lacks detail on its emergence, meaning or implication (Adger 2000, Gunderson 2004, Niemeyer et al. 2005, Folke 2006, Walker and Salt 2006, Nelson et al. 2007, Gordon et al. 2008, Biggs et al. 2009, Leslie and McCabe 2013, Carpenter et al. 2015). Many commentaries use the concept rhetorically in passing to communicate that regime shifts are often unpredictable, more rapid than expected (Schneider et al. 2007:785), difficult to adapt to, and will hence be experienced as "surprising", as seen from the point of view of the external analyst. But how exactly surprise develops and how it differs from similar concepts such as disturbance, perturbation, shock, or bifurcation is, with some exceptions (Kates and Clark 1996, Folke et al. 2005), left outside of the analyses.

In this paper, I re-emphasize Holling's original concern that not all systemic shocks are the same, nor of the same impact. Shocks that are surprising have a much more significant impact on adaptive management capacities than those that were anticipated. This notion resonates more clearly with the original idea of a bifurcation (Guckenheimer and Holmes 1983), which is defined as a change in the qualitative behavior of the system (Ludwig et al. 1997). Surprise brings such qualitative change. Military surprise attacks, referred to as "strategic shocks", are said to jolt convention to such an extent that they force affected institutions to fundamentally reorient strategy, strategic investments, and missions (Freier 2008). Strategic shocks are seen as qualitatively different from other contingencies (e.g., "normal" shocks) because of their combination of wide-ranging impact and the way in which they stretch conventional wisdom or are outside the "normal" (Schwartz and Randall 2007). Thus, a disaster that emerges under conditions of surprise may be what truly alters systemic trajectories and deepens the impact. This additional impact, as well as its associated human cultural dimension, is difficult to capture in system analyses of resilience. After all, systems do not experience surprise; only humans do. This means that in social-ecological interactions, information about human experience, in particular meaning-making processes, needs to be integrated to understand political receptivity to early warning 
signals. More than a decade ago, some pointed at the key role of collaborative learning and trust as well as the importance of multidisciplinary and lay knowledge to deal with the inevitability of surprise (European Environment Agency 2001, Folke et al. 2005). Others argued for political awareness of windows of opportunity; periods in which management action to avert a regime shift is more than typically possible (Kates and Clark 1996, Biggs et al. 2009) or which exacerbate pressure for socio-political change (Klein 2007, de Vries 2017). What emerges from all this is that the concept of surprise is of central concern to resilience studies but is still relatively underdeveloped. Should surprises be treated as subcategories of generic systemic shocks? Does it suffice to look at them as rhetorical tools to attract the attention of policy-makers who are needing to address early indicators of regime shifts? Or should we pay extra attention to surprises?

Building on ideas from historical ecology (Crumley 1994, 2002, de Vries 2008) and anthropological disaster and vulnerability research (Hoffman and Oliver-Smith 2002), I argue that the collective experience of surprise differs qualitatively from notions of the generic "disturbance" or even more from the cultural notion of "shock" (Wallace 1957). What is at stake is what Kai Erikson pointed out decades ago: that disasters influence what is of worth for the self (Erikson 1994). In the case of surprise, it is our experience of temporality, our ideas about past, present, and future, which may shift and loose meaning. This means that analysis should not just be about ecological surprise - which exists only in the mind of the systems theorist - but should also include the much more complex notion of social-ecological surprise. Because surprise is a human emotion, to understand it we must by necessity include a perspective that starts from the cultural view of people on the ground ("emic"). Such perspective not only makes surprise analysis localized - as each landscape has its own hazard history-but also temporally situated, because how cultural meaning is derived depends on the moment of analysis. Because such investigations broadly characterize anthropological understandings, I believe that it is this type of knowledge that needs to be integrated and contrasted with historical ecological information to identify when and where Holling's discrepancies between shared expectations and objective reality may develop. Based on these premises, I propose an approach that reframes the idea of social-ecological surprise as an issue of vulnerability. Foremost, this means that a "surprise" is not just an event but the outcome - the symptomatic expression - of a much longer term, historical process of coupled human-environment interactions. I use four North American floodplain case studies to illustrate how this vulnerability is temporal. Surprise deals with expectations that are uniquely informed by the culturally determined experience of time (also called social time) associated with human meaning-making processes. My analysis builds on Holling's macroview of surprise but deepens it by proposing an analysis at community level from a vulnerability perspective.

\section{A temporal vulnerability}

Surprise distinguishes itself from the concepts of risk and uncertainty. To calculate risk, outcomes and probabilities are deemed known. Under uncertainty, only the outcomes are known. True surprises, however, when defined in their most narrow form, cannot logically be foreseen "because the very act of anticipation implies some level of knowledge" (Schneider and Turner 1994). Such narrow (or "true") surprises-also referred to as Black
Swans in economics (Taleb 2007) - arise in situations where there are structural inabilities to know, including shared, communal ignorance. Because the impossibility of anticipating such situations often means that lessons learned are difficult to derive (and instead are often inappropriately rationalized after the fact with the benefit of hindsight), attention typically goes to assessments of "surprises" where events, processes, and outcomes were to some extent "knowable". This second type of surprise has also been called a "predictable surprise" (Bazerman and Watkins 2004). The Hurricane Katrina disaster of 2005 in the United States is an example, as knowledge of the possibility of floodwall breaches was present at certain governance levels, which demands political explanation of why this knowledge did not disseminate further (Irons 2005). But what if we see the difference between predictable and narrow surprises as a continuum, and ask ourselves how, as human agents, our actions and intentions influence where we end up on this "scale of ignorance"? Should we not at least try to analyze what processes make us slip from predictable (knowable) surprise conditions into the abyss of the completely unknowable? Or, what mechanisms and processes can be documented that make us vulnerable to social-ecological ignorance?

In "high-risk organizations" that have complex coupling of processes and potentially disastrous consequences if those processes fail (e.g., hospitals, chemical factories), much effort is expended to develop safety cultures in which the pendulum of surprise is forcibly kept at the predictable end. Safety cultures describe the organizational atmosphere or culture in which safety is understood to be, and is accepted as, the number-one priority (Cooper 2000). Safety cultures show a dominant focus on improving information-processing capacity. Medical organizations that have experienced relatively few catastrophic incidences appear preoccupied with failure and organizational learning, control of work processes, insertion of safety barriers along accident trajectories, and a situational awareness that focuses on knowing what is happening now, what happened in the past, and what will happen in the future (Weick and Sutcliffe 2001, Duijm 2009). These practices suggest that dynamic processes exist which destabilize predictability, and that collective, situational awareness of these processes is key to avoiding surprises. Bringing such awareness into social-ecological systems, disaster researchers have long pointed to the need for analysis of the root causes that produce unsafe conditions, called the "vulnerability approach" (Blaikie et al. 1994, Cutter 1996, Hoffman and Oliver-Smith 2002, McCoy 2013, Wisner 2016). Vulnerability defines the extent to which a system has been historically conditioned to be susceptible to, or unable to cope with, the adverse effects of hazards. It depends not only on a system's sensitivity but also on its adaptive capacity (IPCC 2007). Applied to collective surprises, a vulnerability lens opens the possibility of a "forensic" analysis of the dynamic processes and root causes that lead to the collectively experienced surprise outcome (Blaikie et al. 1994, Wisner et al. 2012, Oliver-Smith et al. 2016). Why does a hazard event turn out to become more, or less, expected? When surprise is seen as the result of complex, long-term processes instead of disconnected, external "accidents" (Kates and Clark 1996, Perrow 1999), this would also imply that a vulnerability perspective renders surprise a condition rather than an event. 
Reverting back to Holling's theory of surprise, a vulnerability analysis of surprise conditions may specifically try to tease out how local cultural conceptions, behaviors, and actions end up producing alternative expectation realities. Arguably, such expectations, however complex, are typically based, in our evidence-based culture, on what we know and have learned from the past, either individually or as a cultural group. Few exceptions exist (e.g., philosophical treatise, or fantasy). Scientific models that may seem asynchronic are typically based on historical time series data that are needed to project expectations onto simulated futures. This centrality of learning from the past suggests that the underlying analytical dimension of the condition of collective surprise cannot be limited to cognitive risk perception (Yudkowsky 2011). While denial of risk resulting from the desire for everything to be normal is an element that can motivate surprise (Festinger 1957, Hendrickx et al. 1993, Omer and Alon 1994, Wade-Benzoni 1999), collective surprise experiences also have to be analyzed historically in their wider interaction with social-ecological forces. Because of this, the appropriate point of departure for this historical analysis of expectations is the human experience of temporality, or our human "being in time". Anthropological "temporalization" emphasizes how symbolic and meaning-making processes are continually being produced through everyday human practices (Munn 1992). However, capturing people "in" such socio-cultural time is difficult. Humans themselves hardly recognize that their experience of time is a cultural construction (Connerton 1989, Nora 1989, Halbwachs 1992, Ingold 1993, Núñez and Sweetser 2006). Arguably, surprise events make us aware of the fragility of this entire construction. Surprise events force a different outlook on our past, present, and future situation, and such shifts in meaning can be unsettling. This is why surprising events heighten shock and also why this vulnerability becomes a "temporal" vulnerability (de Vries 2007, 2008). The temporal vulnerability lens builds upon terminology used previously in studies on the neurological effect of alcohol exposure (West 1987) and informed consent (Tolich and Baldwin 2005). A temporal vulnerability approach demands an anthropological and historically "presentist" stance, or an analysis of how the current momentthe "now"-is culturally constructed and potentially compromised or biased (de Vries 2011a). It is important here to distinguish the experience of collective surprise from its historical conditioning. Collective surprise experience is merely the expression - or outcome - of a particular historical vulnerability process and indicates the existence of its conditions only after the fact (Alexander 2000).

As an example, traces of past floods are embedded in experiential personal memories, oral histories retold across generations, historical archives, landscape architecture, and other forms of cultural, physical, or social memory (Crumley 2002). Because these forms of memory are linked, together telling the story of how people experience time, these "memory-networks" orient the expectations actors have of the future. In some social networks, such as neighbors in a low-income floodplain area, people may rely strongly on oral histories and lived experience. Higher income coastal property owners participating in flood insurance schemes may rely instead on consultants and expert data. Such differences are sociological and have historical trajectories. Berkes and Folke (2002), for example, have pointed out that traditional, local environmental management systems which excel particularly in the capturing of long time series of local observations have in modern times been increasingly complemented, and often replaced, by a reliance on scientific measurement and management, which excels in the collection of simultaneously observed data, yet has a relatively shallow time-depth. Documenting historical transitions in such memory-networks and uncovering how this sociology of difference influences expectations should be a key focus of any temporal vulnerability assessment. How vulnerable are these memory-networks to "loss" of information? How well do evaluators reference lessons from the past when they actively bring them into present moments of evaluation? The analytical inquiry investigating expectations becomes an effort to understand if, when, and how populations or communities end up becoming constrained or compromised in their ability to reference collective histories temporally. Following this historical ecological approach (Crumley 1994), an assessment can be made of how far some communities may have lost touch with historical ecological reality, and how, while sliding toward historical ignorance, these factors facilitate the conditions for collective surprise. After all, the less our expectations are based on what happened in the past, the more wildly divergent our future projections become.

As Plümper et al. (2017) have recently pointed out, in the context of disaster studies, most of the emphasis has been on the uncritical assumption that learning has only beneficial impacts, which ignores how learning from natural disasters can also have detrimental consequences if protective infrastructures create a false sense of security. Others have written on pathological adaptations in the context of sustainability, such as the safe development paradox (Burby 2006, Kates et al. 2006, Westley et al. 2011). Yet, a deeper focus on the consequences of cultural and institutional memory in its linkage to systemic vulnerability has been rare in disaster contexts. A few conceptual moves have been made to combine the experience of temporality with vulnerability studies (Forrest 1993, Bankoff 2004, National Research Council 2006, de Vries 2007). Possibly, this lack of attention results from the idea that "temporality" is de facto included in historical analysis (Oliver-Smith 2012) and operates on a chronological dimension. This, however, ignores the fact that expectations-so crucial for understanding surprise conditions-are socialcultural constructions that operate in social (not chronological) time. For example, the well-known Pressure and Release model does point at the relevance of capturing experiences of past events as a "human resource", reducing fragile livelihoods and unsafe locations (Wisner et al. 2012). Yet the model describes root causes as "temporally distant (in past history)", thereby removing their relevance in the here and now (Blaikie et al. 1994:52). Furthermore, it lists different types of hazards without taking into account how their particular timing affects human expectations. What this model ignores is that our experience of time itself is not an objective but a subjective category that includes memory in the here and now (Crumley 2002, Barthel et al. 2010).

Using data collected in four floodplains in the United States, I have for this study explored how surprise conditions emerged from the interaction between three dynamic systems. First, there is the "mnemonic" (Zerubavel 2003) or the memory and experiencebased lens of the past, which is collectively used to orient 
expectations and judge new events. This can be seen as a cultural model maintaining continuity between events disparate in time for which considerable mental bridging is required and that enable prediction and explanation, and are cultural because they are shared and reproduced within a culture (Holland and Quinn 1987). Such cultural models are illustrated in remarks by respondents or in newspaper archives that a certain flood event was "the worst in 50 years". The second dynamic system is the dynamic landscape (Crumley 1994), which involves the extent to which landscape changes relevant to the flood cycle were occurring and detectable by those evaluating and monitoring their environment. This may include issues such as seasonality. The third dynamic system includes what we call "hazards", or the threats that destabilize predictive, cultural order. As most flood hazards do not occur predictably but in a relatively random fashion, this nonlinear distribution of the hazards through time influences the meaning attached to associated reference-making practices.

Using this typology, the remainder of this paper summarizes the findings of this analysis. The work identifies a number of interactions within and between the three dynamic systems that drive temporal vulnerability. The resulting model integrates analysis of hazard, landscape, and socio-cultural factors, with the results broadly divided into three categories: (1) structural inabilities to know (ignorance), (2) memory-networks and transitions (naivety), and (3) cognitive dissonance and cultural indifference (denial). A summary of the mechanisms documented under each thematic-ignorance, naivety, and denial-is provided in Table 1.

Table 1. Mechanisms influencing collective surprise conditions, by thematic

\begin{tabular}{|c|c|c|}
\hline $\begin{array}{l}\text { Ignorance: } \\
\text { lack of temporal } \\
\text { references }\end{array}$ & $\begin{array}{l}\text { Naivety: } \\
\text { erosion of temporal } \\
\text { referencing practices }\end{array}$ & $\begin{array}{l}\text { Denial: } \\
\text { misguided temporal } \\
\text { referencing practices }\end{array}$ \\
\hline $\begin{array}{l}\text { Uncertainties } \\
\text { inherent to hazards } \\
\text { themselves }\end{array}$ & $\begin{array}{l}\text { Misguided collective } \\
\text { baseline reference }\end{array}$ & $\begin{array}{l}\text { Cognitive dissonance } \\
\text { reduction }\end{array}$ \\
\hline $\begin{array}{l}\text { Lack of historical, } \\
\text { time-series, or } \\
\text { archival data }\end{array}$ & Flukes & Casual amnesia \\
\hline $\begin{array}{l}\text { Colonization of a } \\
\text { pristine floodplain } \\
\text { landscape }\end{array}$ & $\begin{array}{l}\text { Misunderstanding of } \\
\text { recurrence language }\end{array}$ & Technological optimism \\
\hline $\begin{array}{l}\text { Rapid change in the } \\
\text { temporal properties } \\
\text { of the landscape }\end{array}$ & $\begin{array}{l}\text { Weakening of cultural } \\
\text { and institutional } \\
\text { memory }\end{array}$ & Scalar confusion \\
\hline $\begin{array}{l}\text { Cascading } \\
\text { interactions }\end{array}$ & $\begin{array}{l}\text { Attrition of flood } \\
\text { generations }\end{array}$ & Lack of feedback \\
\hline $\begin{array}{l}\text { Failure of } \\
\text { environmental } \\
\text { monitoring systems }\end{array}$ & $\begin{array}{l}\text { Some mitigation } \\
\text { actions }\end{array}$ & \\
\hline
\end{tabular}

These factors all have in common that they are related to temporal reference-making practices, and through these activities not only influence the human experience of time but also provide explanatory entries into an analysis of surprise conditions. The aim of this model is to provide an initial starting point for further exploration of how temporal vulnerability could be more rigorously measured, and exploration of possible strategies to reduce conditions of collective surprise or build what may be called "temporal resilience".

\section{METHODS}

\section{General methodological framework}

A general interpretivist epistemological framework was used initially, which focused on the (emic) perspective of the people involved. An interpretive approach explores the intentional states that motivate individual actors (Weber 1978), or "the action frame of reference" (Parsons 1937:43-51). My methodological orientation incorporated actor-network theory (Latour 1988, 1999). This theory seemed fitting because there is not one exclusive human or nonhuman factor that temporally orders and connects the collective experience of surprise. Instead, the analysis is about a web of subjects (e.g., floodplain residents, government officials, scientists) and objects (e.g., floodplain maps, monitoring devices, neighborhoods) which together, in specific local configurations, orient people's expectations for the future. Furthermore, Latour (1999) described how physical soil samples are turned into references in books, suggesting that a focus on the quality of such referential transformation should be central to the analysis. In this study, in addition to looking at the quality of such chains of transformation "within" time (asynchronic), I also reinterpreted the chain to examine how translations bring the past back into the present. I particularly looked at how such processes of translation include selective distortions, silences, or erasures. While actor-network theory does not explicitly focus on temporality, the idea of the temporal referent appeared extremely helpful in understanding the linkage implied by respondents or documents between the past and the present because it reoriented analytical attention to the quality of such chains of temporal transformation. For example, when a mitigation manager mentioned how flooding had increased over time, which "reference model" served as a comparative baseline for this evaluation? The big city flood, or the most recent local neighborhood flood? I consistently asked myself which factor made such remembering of flood elements (e.g., location, water depth, pollution, injuries) more difficult to achieve. What factors, then, weakened practices of temporal reference-making? Combining actor-network theory with a qualitative grounded theory approach (Glaser and Strauss 1967), conceptual sensitization after repeated analysis and re-entry into the field, increasingly led me to focus on this notion of temporal referentiality, or how references were made to past events, and how the quality of those references influenced memory-networks and resulting expectations (de Vries 2011a).

\section{Methods and field sites}

Historical research, qualitative open-ended interviews with key respondents, ethnographic observation, and limited spatial mapping and quantitative analysis were all used in an iterative grounded theory approach (Glaser and Strauss 1967) to study four urban floodplain neighborhoods in the United States from 2000 through 2005 (Fig. 1).

The neighborhoods were located in the City of Kinston (North Carolina), City of Savannah (Georgia), City of Harvey (Louisiana), and Town of Felton (California). The criteria for choosing these sites included the historical depth of flood experience, biophysical diversity (riverine and coastal), and high 
Table 2. Field sites with flood characterizations

\begin{tabular}{|c|c|c|c|}
\hline Neighborhood & Location & Flood characteristics & $\begin{array}{l}\text { Population change }(\%) \\
\text { for the surrounding city } \\
\text { or county } \\
1970-2010 \dagger\end{array}$ \\
\hline $\begin{array}{l}\text { Maplewood, City of } \\
\text { Harvey, Louisiana }\end{array}$ & $\begin{array}{l}\text { East of the Intracoastal Canal along the } \\
\text { Mississippi West Bank in Jefferson Parish (New } \\
\text { Orleans Metropolitan Region). The neighborhood } \\
\text { stretches south along Manhattan Boulevard. }\end{array}$ & $\begin{array}{l}\text { Frequent rainstorms and risk of major } \\
\text { storm surge due to Gulf of Mexico tropical } \\
\text { systems. Prone to flooding due to complex } \\
\text { hydrological landscape. }\end{array}$ & $321 \%$ \\
\hline $\begin{array}{l}\text { Ardsley Park, City of } \\
\text { Savannah, Georgia }\end{array}$ & $\begin{array}{l}\text { South of present-day Victory Drive and north of } \\
\text { Columbus Drive. While the western edge is } \\
\text { situated on high ground, the eastern portion is } \\
\text { former swampland. }\end{array}$ & $\begin{array}{l}\text { Frequent rainstorms and risk of major } \\
\text { storm surge due to Gulf of Mexico tropical } \\
\text { systems. Prone to flooding due to outdated } \\
\text { drainage systems. }\end{array}$ & $115 \%$ \\
\hline $\begin{array}{l}\text { Lincoln City, City of } \\
\text { Kinston, North Carolina }\end{array}$ & $\begin{array}{l}\text { Former African-American riverine neighborhood } \\
\text { in the southeast of Kinston. Residents } \\
\text { participated in a federal buyout program after } \\
\text { Hurricanes Fran and Floyd, and the } \\
\text { neighborhood has since ceased to exist. }\end{array}$ & $\begin{array}{l}\text { Prone to relatively frequent minor as well as } \\
\text { major riverine flooding as a result of } \\
\text { tropical systems. }\end{array}$ & $97 \%$ \\
\hline $\begin{array}{l}\text { Felton Grove, Santa Cruz } \\
\text { County, California }\end{array}$ & $\begin{array}{l}\text { In the Town of Felton, located in a mountainous } \\
\text { environment along the convergence of the San } \\
\text { Lorenzo River and Zayante Creek. Formerly a } \\
\text { summer camping destination. }\end{array}$ & $\begin{array}{l}\text { Frequent riverine flash flooding, } \\
\text { complemented by other hazard (e.g., fire, } \\
\text { earthquake, mudslides). }\end{array}$ & $212 \%$ \\
\hline
\end{tabular}

number of repetitively flooded properties (properties that had at least two flood insurance claims of more than US\$1000 since 1978 , or two or three claims that equalled or exceeded the buildings' value). In each location, access to the mitigation bureaucracy was facilitated through previous fieldwork conducted for the Federal Emergency Management Agency (Fraser et al. 2005). This fieldwork was complemented by additional interviews with floodplain residents using a purposive sampling approach. Location and flood characteristics are shown in Table 2. These sites were ideal for answering the research questions because, in each, a collective surprise experience had occurred, while the four sites shared relatively similar riverine and repetitive loss floodplain contexts.

Fig. 1. Four coastal case study sites in the United States.

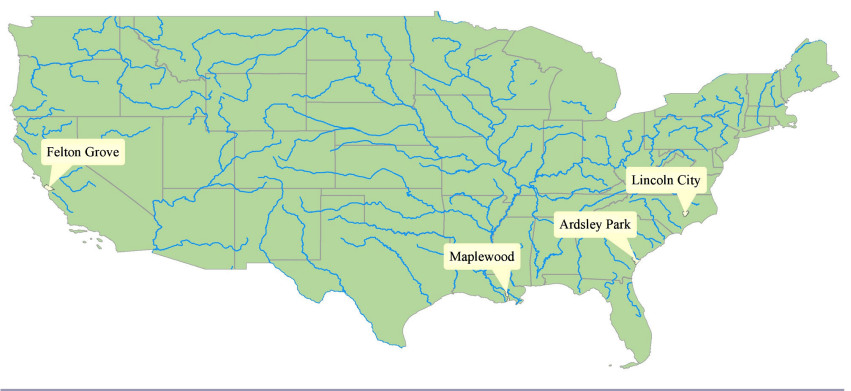

A proxy measure for the timing of hazards across the four counties in which these neighborhoods are located is shown in Fig. 2. These temporal flood signatures were created by aggregating property damage figures (adjusted by inflation to 2016) from the Spatial Hazard Events and Losses Database for the United States (SHELDUS ${ }^{\text {TM }}$ U.S. 16.1) (CEMHS 2018). Data from 1961 through 2005 were used. This presents the historical experience at the time fieldwork ended. As such, these signatures lack significant events that have since affected these localities. In addition, these flood-related impacts may not have occurred in the studied neighborhoods because the scale is at the county level. Still, the graphs provide an indication of the diverse, historical flood contexts of the case studies.

Qualitative methods included participant observation through dwelling in the floodplains but consisted mostly of formal, openended, audio-recorded interviews with respondents ( $n=75$ across all sites), which lasted, on average, two hours. In addition, I collected information through numerous informal conversations in various settings, ranging from formal meetings to bars, and drove through neighborhoods with flood victims or mitigation officials, which I documented in field notes. Archival work consisted mostly of visits to local libraries and extensive searches of historical newspaper records, drainage committee meeting minutes, and other historical reference materials. In addition, I spent time finding records online and searching discussion boards, online archives, and other internet resources. Complementing the qualitative methods, I also explored local and U.S. Census 2000 data, which I overlaid on spatial maps (ArcGIS). This mix of data and methods allowed me to shift my perspective spatially, temporally, and cognitively. Overall, I traveled to 11 floodplain communities for about five years between the summer of 2000 and winter of 2005 while working within the mitigation research field for three years, funded through the U.S. Federal Emergency Management Agency. Informed consent was used with all respondents, and included confidentiality and anonymity of the responses. An internal ethics review was conducted through the University of North Carolina at Chapel Hill's Department of Anthropology.

\section{Analysis}

All data were organized using Nvivo qualitative software for transcribed interviews, SPSS statistical software, ArcGIS spatial analysis software, and Excel spreadsheets. Initially in the study, an a-priori coding scheme was used based on applied fieldwork 
Fig. 2. Property damage time series, 1961-2005 (CA: California; GA: Georgia; NC: North Carolina; LA: Louisiana) (Source: SHELDUS).

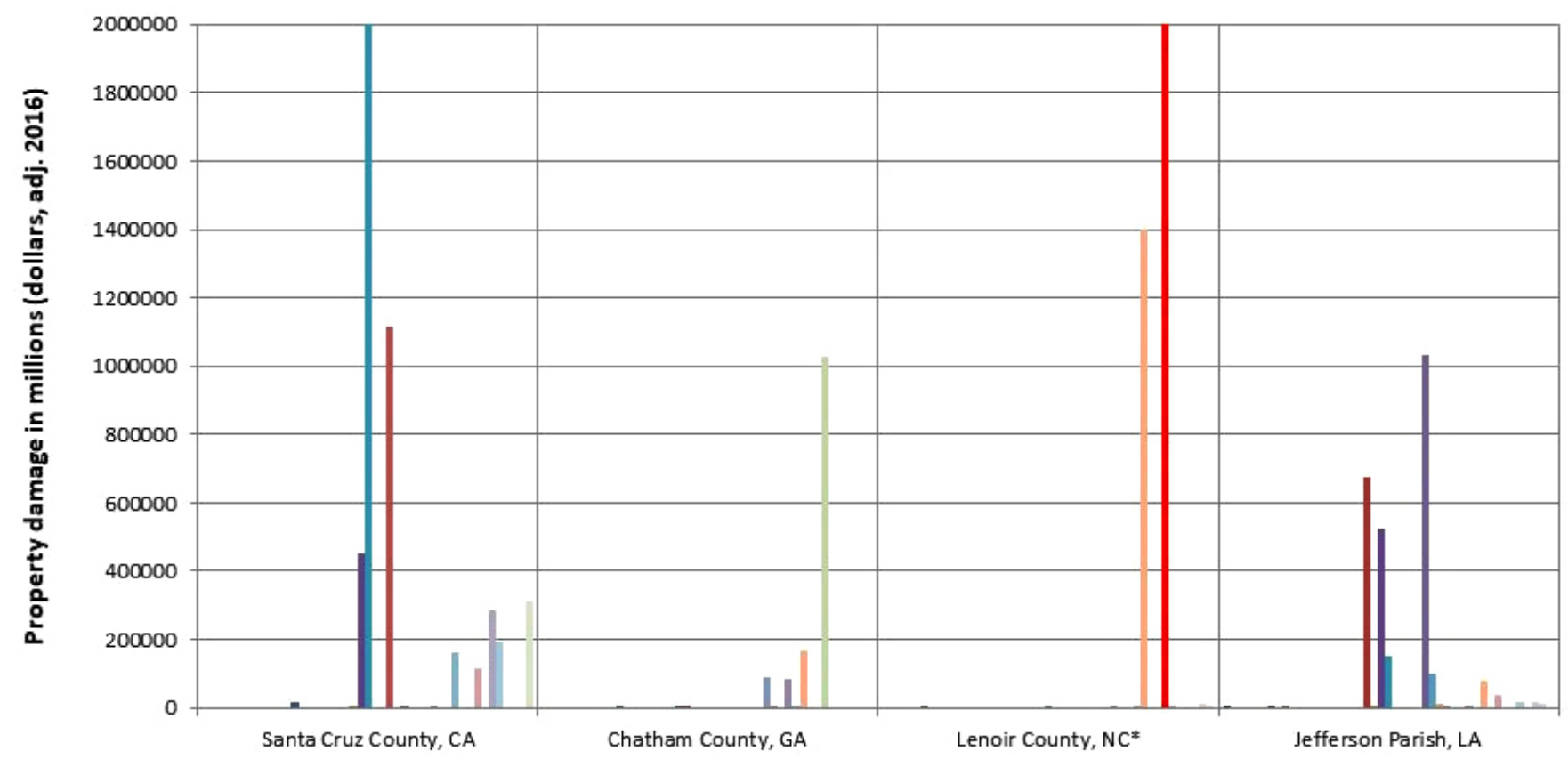

Period of 1961-2005 (left to right) for each county in which field site is located

* Damage data for 1999 Hurricane Floyd (red) was lacking in SHELDUS database and has been estimated based on 1996 Hurricane Fran (orange).

that focused on mitigation decision-making in the four repetitiveloss floodplain neighborhoods, based on qualitative interviews with mitigation managers at local, state, and regional levels. Main codes included demographics, history of the neighborhoods affected, perceived flood risk, land use conflicts, perceived barriers to participation in Federal Emergency Management Agency (FEMA) mitigation programs, citizen-government relationships, residential attachment to property and neighborhood, and perceptions of FEMA's buyout and elevation program, including staffing and retention issues. These codes were complemented by open-ended coding of emerging themes, one of them related to issues of historical memory, the experience of forced relocation, and surprise. After re-entry in the field, an inductive approach was used with open coding that allowed for themes around the issue of surprise to emerge. Initially, a key question asked was how certain floods had surprised people. My aim was to distil the different conditions that sustained temporal vulnerability before surprise events. This included knowledge on what decision-makers, evaluators, residents, or other stakeholders understand or know about the history of their landscape, how this historical knowledge is constructed by scientists and experts, how this narrative is influenced and translated by other communication channels, and how it finally shapes risk expectations among stakeholders. Information from this memory-network was used to explain why the conditions for surprise emerged. The major coding categories that emerged from this exercise were casual amnesia, disbelief potentiality, environmental, memory, politics of predictable surprises, reduced tolerance, and scientific uncertainty.

\section{RESULTS}

In the following sections, I describe interactions between human perceptions, landscape changes, and hazard timing across the four case studies. The results are written up using three categories that together describe how these interactions influenced conditions of surprise across the four case studies: (1) lack of temporal references, relating to structural inabilities to know, or ignorance, (2) erosion of temporal referencing practices, which deal mostly with memory-networks and knowledge resource transitions leading to naivety, and (3) misguided temporal referencing practices, typically dealing with issues of cognitive dissonance and cultural indifference broadly leading to denial. Afterward, a summary of all mechanisms is provided in order to derive the notion of temporal resilience.

\section{Lack of temporal references (ignorance)}

This first classification deals with causes of ignorance, or structural inabilities to know, which relates to the boundaries of phenomenological and epistemological knowledge. These conditions typify earlier defined "narrow" surprise conditions. For example, in Jefferson Parish before Hurricane Katrina struck in August 2005, several mitigation managers complained that not knowing when to evacuate was a serious problem, since forecasters could not tell exactly where or when a hurricane would hit until it was too late to evacuate. Complicating this structural ignorance was the anticipated impact of climate change, which people believed would shift the hazard norm in various places. Historical references were often made to illustrate such a shift. For example, one Jefferson Parish respondent noted that 
"drainage" did not become part of the common vocabulary until a decade of unprecedented heavy rains beginning in 1978 introduced drainage problems, referring to the influence of climatic change on flood conditions.

Such conditions for surprise, however, are most acute when hazard uncertainty interacts with landscape change. For example, as flood levels became regulated along the Neuse River in North Carolina due to the building of the upstream Falls Lake Dam in the 1980s, Corps of Engineers dam managers explained the difficulty of calculating how much water could safely be released from the reservoir without flooding downstream communities. This ability had become constrained as a result of landscape changes. After operations started in the 1980s, a coincidental extended drought period facilitated land development in formal floodplain sites just downstream of the dam. Adding to this was a miscalculation in the volume of the reservoir - which appeared smaller - and the result was a need to let water go earlier in the face of approaching rainfall events. With less time to plan, monitor, and assess, the impact of hazard uncertainty was amplified, and this increased the conditions for surprise during Hurricanes Fran (1996) and Floyd (1999).

Human landscape alterations thus influence hazard uncertainties and the speed of impact, and increase temporal vulnerabilities, particularly if people are not aware of these processes. But this interaction can be much subtler. An example is the "vulnerable times", or calendric categories, schedules, or periodizations which suggest that some windows of time are more vulnerable than others. This view is present in the original conceptualization of the temporal vulnerability concept in neurobiology (West 1987), and later patient vulnerability (Tolich and Baldwin 2005). Here, this refers to reoccurring alterations in the dynamic states of the floodplain. In a "natural" example, the summertime tranquility of the San Lorenzo River contrasts greatly with the raging river seen after a February winter storm. A more socio-cultural example is how in the City of Savannah, flooding occurs mostly in early evening in summertime, when commuters drive home from work, which leads to more traffic accidents. While this may also heighten flood awareness, and as such reduce surprise conditions (after all, we anticipate), when this schedule coincides with high tide, the normal flood's temporal properties are sped up and intensified, creating yet again opportunities for surprise, particularly for residents who do not have long-standing experience with such deviations from schedules. So why commute during these hours? A further complicating element here may also be the speed with which the systemic states alternate. Looking again at the San Lorenzo River in Santa Cruz County, flash flooding clearly compromises residents' ability to react in a timely fashion and exacerbates existing hazard uncertainty.

Narrow surprise conditions do not develop only as a result of hazard uncertainty in interaction with landscape changes or schedules, but can also be forced by landscape alterations alone. A regularly mentioned example of this was the tight coupling of large drainage infrastructure projects, causing cascading risks, popularized as leading to "normal accidents" by Charles Perrow (1999). The complex hydrological environment of the New Orleans region in the wake of Hurricane Katrina has been analyzed from this perspective (e.g., Leavitt and Kiefer 2006, Sims 2007). One of my elderly informants from the City of Harvey explained how an area that had been on higher land suddenly flooded because the building of Jefferson Highway acted as a trap for rainfall floating away from the natural levees of the Mississippi River. Engineers had not foreseen this possibility, and the culverts were too small in diameter to avoid unexpected flooding to the south. Similarly, respondents from the Maplewood neighborhood complained about the slow drainage of water through their neighborhood's canals. They pointed to a pumping station located $4 \mathrm{~km}$ (2.5 miles) away which was impacted by different microclimatic conditions. Because pumps need a certain depth of water to maintain hydraulic pressure, they were not always activated in time to help drain their neighborhood. Arguably, these are simply planners' mistakes. Yet, as Perrow argues, when interactions become complex, accidents will at some point selforganize. Overly complex drainage systems, then, can forge a loss of predictable surprise. Why not introduce simpler solutions?

There is yet another finding that shows how we make ourselves more vulnerable to narrow surprise conditions. The four case studies show how the capacity of residents to discern meaningful difference in their environment can be highly compromised as a result of perceptually "pristine" conditions (Alexander 2000). For example, when white settlers started living in large numbers along the San Lorenzo River floodplains in California in the late 19th century, they had only shallow historical ecological knowledge about San Lorenzo Valley flood history, except for what might have been obtained from Native American tribes and early settlers affiliated with church missions. Comparatively speaking, settlers in the City of Savannah might historically have had more opportunities to obtain experience or local information from Native American tribes due to the earlier date of colonization (if they talked at all). However, even in cases where inhabitation has a relatively deep and celebrated history - e.g., European contexts - there can still be a lack of availability of historical information needed to discern such difference. The case of Savannah is illustrative of this. In its archives, flood data were completely missing between 1928 and 1955 as a result of a financial crisis that almost ruined the city and compromised archival quality. When I spoke to city engineers, it appeared they were using a database on structural flooding with a mere 20-year history, even though the city itself was first founded in 1733. Why not use deeper historical knowledge? A similar case was described for the City of Kinston, where floodplain maps had been calculated based on only 18 years of data, despite a much older history and deeper experience (de Vries 2011a). Depending on the real historical range of river heights, these floodplain maps institutionalized conditions for temporal vulnerability.

But environmental monitoring systems can also fail completely. While the pumping problem for Maplewood residents may not have resulted from an inability to monitor but instead from cascading interactions, in the City of Savannah the ability to measure rainfall in the city on a real-time basis was compromised by locating the rainfall gauge at the airport, situated $32 \mathrm{~km} \mathrm{(20}$ miles) from the ocean. In a coastal landscape where distance means substantial microclimatic change, city engineers noted how this discrepancy could make a decisive difference in knowing when, and if, a flood would occur, thereby increasing hazard uncertainty. A similar situation affects the mountainous landscape of Felton Grove, California. Emergency Services officials indicated that the "surprise storm" of 1998 came in "just 
Table 3. Homeowner turnover rates in Felton, California area (source: Santa Cruz County GIS)

\begin{tabular}{lccc}
\hline \hline $\begin{array}{l}\text { Type of landscape (County of Santa } \\
\text { Cruz definitions) }\end{array}$ & $\begin{array}{c}\text { Number of parcels } \\
\text { sampled }\end{array}$ & $\begin{array}{c}\text { Mean turnover (properties/ } \\
\text { year) } 1984-2005\end{array}$ & $\begin{array}{c}t \text { test of difference in mean compared to "No } \\
\text { floodplain” reference category }\end{array}$ \\
\hline No floodplain & 1669 & 2.2 & 2.4 \\
Floodplain & 244 & 2.5 & $t(1905)=-1.87, p=.06^{\star}$ \\
Floodway & 204 & 2.9 & $t(248)=-2.74, p=.001^{\S}$ \\
Felton Grove & 40 & $t(1704)=-2.82, p=.0005^{\star}$ & $p$ \\
\hline
\end{tabular}

${ }^{\dagger}$ Floodplain includes floodway and Felton Grove, etc.

"Equal variances assumed using Levene's Test for Equality of Variances

${ }^{\S}$ Equal variances not assumed

underneath" the monitoring network's threshold of detection, so the hazard remained undetected until its impact had increased to a much broader scale. Why then did the county cut funding for several monitoring gauges? Environmental monitoring problems also plagued the levees in New Orleans, which were closely monitored "on paper" while in reality this monitoring quality control was inadequate (Davis et al. 2006). Concurrently, longterm concerns expressed by Gulf Coast fishermen and coastal residents about the rate of wetland loss documented by sociologists (Burley et al. 2007) were left unheard by political powers until it was picked up by environmentalist and scientific communities and popularized in the 1990s (Hecht 1990, Tidwell 2003). Politicians were more inclined to believe in the technological mastery of nature, while supporting the damaging environmental practices of the oil and gas industry (Morton et al. 2002).

Erosion of temporal referencing practices (naivety)

Hazard uncertainties, landscape complexities, schedules, and human monitoring systems forge narrowing of surprise conditions. These pathways of surprise appear further impacted by socio-cultural and demographic processes. On the cultural side, how is meaning derived from the perceived randomness of hazard events or the changes occurring in the landscape? Some common elements can be discerned. First, generations of floodplain residents tend to share a common baseline reference flood used to calibrate meaning to new or projected events. For example, in Greater Metropolitan New Orleans, the baseline reference of 1965 Hurricane Betsy continued to provide a false sense of security to the elderly during the pre-impact Katrina emergency preparedness phase. Having survived Betsy in their homes, many decided not to evacuate (de Vries 2011b). This finding echoes the psychological anchoring and adjustment bias (Tversky and Kahneman 1987).

Baseline references also continue to influence expectations after impacts, as seen in the case of the "fluke". To residents in the Kinston's Lincoln City neighborhood, the baseline reference event of Hurricane Hazel in 1955, memorized through stories, photographs, public commentaries, and other media, led to an evaluation of the impact of Hurricane Fran 30 year later as "rare", and "not normal". As a result, a local movement developed that blamed dam managers for errors. While this was not without cause (see previous section), what was ignored was the fact that the baseline temporal referent had become sorely outdated as a result of large landscape transformations, including major upstream urbanization that increased runoff. While at governance levels Hurricane Fran was taken up as a serious early warning, to the public the event was perceived as an "accident" or "fluke". This interpretation failed to prepare the public for the impact of Hurricanes Denis and Floyd, which created havoc only three years later (de Vries 2017).

Secondly, the increase of temporal vulnerability because of baseline referentiality is complicated by a pervasive erosion of lived experience and networks of memory. The lack of historical information in the City of Savanna archives from 1928 to 1955 has already been mentioned. Public flood expectations are, however, also based on noninstitutionalized collective memory. In the flash flood environment of Felton Grove, with extreme alterations in river conditions, new residents had difficulty comprehending the seriousness of the flood risk until they personally experienced a flood event. The "sixth sense" that developed among residents who had experienced a flood was testimony to this problem. A group of residents who had uniquely experienced the baseline flood appeared to have a special place in community education and organization, illustrated by their key role in motivating for, and organizing, a neighborhood early warning siren. Yet, when this flood generation decreased in number, the critical mass available to provide adequate emergency preparedness diminished, and transmission of historical flood memory was reduced in quality, thereby moving the system closer to narrow surprise conditions. A similar situation was observed in North Carolina, where elderly residents in Lincoln City knew about risk in their landscape, while younger residents were unable to understand its significance after a 30 -year lull in major events. During the two major buyout attempts of floodplain residents by the local city government, it was mostly the elderly who appeared willing to trust the intentions of officials (de Vries and Fraser 2012).

Third, also at the socio-cultural level, the landscape interacts. The impact of human demographic attrition on memory-networks is made worse by a rapid or regular influx of newcomers. However, in Felton Grove, historical real estate data obtained through the County of Santa Cruz showed that property turnover rates were significantly higher in floodways than in floodplains, and turnover in both hazardscapes was much higher than in nonfloodplain residential areas (Table 3).

This faster-than-usual erosion of historical memory in Felton Grove was further increased by the mitigation actions of the government. Mitigation efforts included elevating flood-prone homes in the neighborhood, which introduced the issue of stairs to climb. This drove out the elderly, who generally carried a deeper historical memory about the local impact of flooding. Like the 
loss of the flood generation, a lack of retention of key personnel at institutional levels also plagued emergency management. In Louisiana, mitigation officials lamented the frequent (re) deployment of military-schooled emergency management personnel to war zones (e.g., Iraq) at state and federal levels. And while disaster mitigation and response funding was tied to disaster occurrences, emergency managers in Santa Cruz and Jefferson Parish complained about brain drain in periods between disaster declarations.

\section{Misguided temporal referencing practices (denial)}

Finally, I delineate a number of factors that are closer to what is referred to as "predictable surprise". These are expectations known at certain levels through, for example, scientific risk assessments, yet unknown at other levels, such as among the wider public. The term "misguided" used here suggests erroneous or biased assessments but not necessarily a lack or mistaken guidance on behalf of the government or some other management body. Often, these issues appeared closely related to psychological issues of denial and/or confusion. Denial has been central to classic psychology, made famous through the concept of cognitive dissonance reduction, or the denial of risk by adjusting cognitions (Festinger 1957). For example, in the high-priced California housing market around Felton Grove, residents expressed the tendency to want to ignore the flood problem as a result of financial dependence on the value of homes. This is because in floodplains, house prices are lower than usual, and while federal and state subsidies exist for acquisition and relocation, this typically means relocating much farther out of the general area to find homes of equal value. Willingness to forget is a theme that often resurfaced. In many cases it can take only a few years until a major flood impact is reduced to an anecdote among those not directly or harshly impacted by it. As one Felton Grove resident described it metaphorically, "It is only when you wake up from your drinking that you think oh my God, this is terrible. And then you sober up, the afternoon comes around, and you forget."

It was striking to see how often motivations to deny expectations were linked to discourses of technological optimism. In all four cases there was a strong influence of the landscape, particularly when new drainage and mitigation structures motivated residents to refer to these improvements as causes for reduced risk, even when such structures may often have had no or little effect on their neighborhood at all. The complexity of drainage systems particularly induced such thinking, as few laypersons were truly able to understand the local hydrogeology, even if it directly affected them. In the City of Savannah, new drainage pumps allowed Ardsley Park residents to argue that a new mitigation project was "overkill" because flooding had now been curtailed, while no 100-year event had occurred to provide feedback on the limits of the pumps in such a situation. Similarly, after 1981, residents in Lincoln City erroneously perceived the river as tamed because of the upstream construction of Falls Lake Dam. Another consequence of technological optimism is that while such technologies aim to reduce physical vulnerability, they often merely end up postponing a breach by heightening the threshold. When the breach eventually does happen, the increased time span between breaches leads to lower levels of experience and hence less preparedness among the population, thereby inducing a surprise condition.
Risk psychologists also refer to the normalcy bias ("ostrich effect"), which suggests that in situations of extreme danger, people may enter a mental state of denial, underestimating the possibility of a disaster by believing the worst would surely not happen, even in the face of evidence to the contrary (Omer and Alon 1994). In each case study, I labeled this tendency a casual amnesia (note: not causal), following Klein (2005). This term refers to an often-found indifference associated with intentional forgetting. In pre-Katrina New Orleans, residents knew their city could be destroyed by a major hurricane, yet to protect normalcy, people I spoke with continued to deny these thoughts much salience. Another form of casual amnesia was expressed in North Carolina. Here, cultural histories of racial segregation meant that historical lack of choice over where to live led to a lack of motivation - or limited communication - to disclose previous floods and a resigned normalization of the existence of "water" in the neighborhood. I observed that such casual amnesia was easily worsened by the distracting cognitive influence of hazards experienced at competing scales, such as common, seasonal "carpet" flooding, which provides a vivid illustration of a "flood," yet did little to accurately portray the impact of a major hurricane. Such scalar confusion was also experienced in the earthquake-, fire-, and landslide-prone Santa Cruz Mountains, which put the flood hazard issue in an awkward perspective relative to the scale of impact of other hazards.

Results suggested that forms of casual amnesia or denial strongly interact with hazard uncertainty, in particular the timing of hazards. Literature has noted this as sparse feedback opportunities that characterize low-probability, high-impact hazards (Irons 2005). Casual amnesia may slip in due to lack of feedback. At the time of this study, the most extreme case of this was seen in the City of Savannah, where a coincidental lack of major hurricane-related storm surge in the past century led to a growing public complacency regarding flood risks. Coupled with increased population growth (Fig. 3), this lack of feedback produces a collective surprise condition for residents.

Fig. 3. Frequency of major and minor hurricanes that affected the City of Savannah up to 2000, compared to population growth.

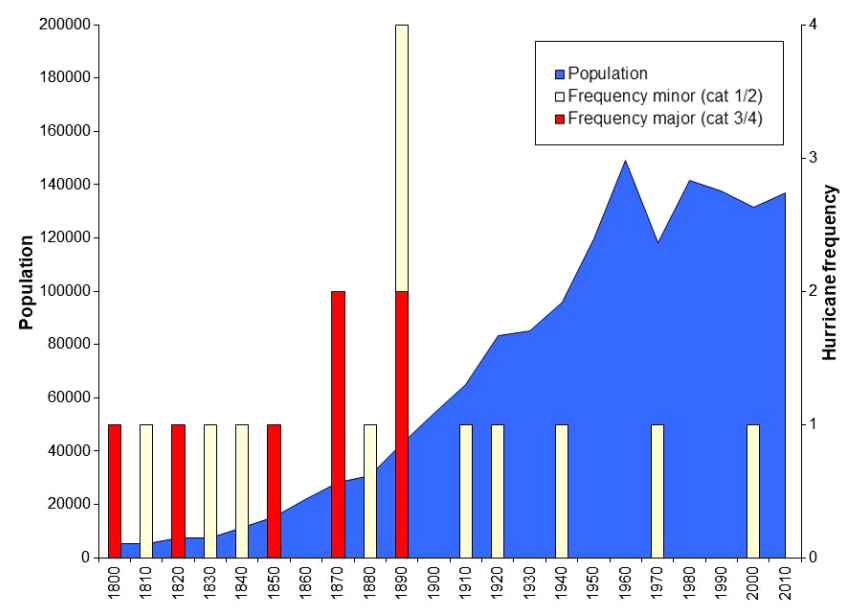


The recent impact of Hurricane Matthew on Savannah in October 2016 may have reduced this temporal vulnerability. However, as the media reported, the storm surge was relatively mild in the end because a direct hit did not occur (Connor 2016).

Finally, confusion further complicates these issues through the common public misunderstanding, or political manipulation, of recurrence language. Misunderstanding of technical recurrence language appears commonly to confuse the public (de Vries 2011a). In all cases studied, residents typically appeared to be under the impression that, for example, a "100-year storm" would mean that if the event had just happened, it would take at least another 100 years for the next one to occur, a process psychologists have dubbed the "gambler's fallacy". The Savannah case was a blatant example. Residents had been told during fieldwork that they had experienced three 100-year rainfall events in a row (1994, 1996, 1999), and looked with (partly justified) suspicion at the city engineers and their urban development projects. As a city official remarked to me, "People think it won't happen again for 10 years or for 100 years. And so, when we had these events occurring in a close period of time, the public begins to mistrust us."

\section{Temporal resilience}

I propose that systematic analysis of factors such as the ones identified here, and summarized in Table 1, can be used to assess temporal vulnerability and then used productively as a tool for the strengthening of what could be called "temporal resilience". It is a bit difficult to conceive what temporal resilience looks like. Translated to surprise, it may be the practice of keeping expectations as close to "objective" reality as possible. Alternatively, if ecological resilience is about absorbing disturbance and still retaining the basic function and structure of the ecological system (Walker and Salt 2006), then temporal resilience may be about learning how to absorb surprise experiences without the consequent trauma of a shifting temporal worldview, or, looking at it from a social-ecological perspective (Holling and Gunderson 2002), without "flipping" our sense of past, present, and future into a qualitatively different state or different temporal basin of attraction (Nicolis and Prigogine 1989).

The building of temporal resilience also calls, arguably, for a reorientation of the meaning of expert knowledge. Trying to identify what we do not know means a willingness to confront other epistemological and ontological perspectives. This would mean a yet greater call for interdisciplinary understanding of the complex interactions between the timing of events, changing environmental conditions, and human meaning-making. Moreover, expertise would no longer reside only in scientific analysis but would also incorporate transdisciplinary valuation of community experiences to broaden insight in the general diversity of historical response, or a post-normal science (Funtowicz and Ravetz 1993, Leslie and McCabe 2013). Temporal resilience may mean that we need collectively to assess, reflect, and communicate better about the politics of what cannot be known, where our naiveties may lie, and in what ways we are denying saliency to predictable surprises.

Pragmatically, temporal resilience may lead to efforts among those dwelling within a hazard system to avoid the narrowing of surprise conditions. It would use social science tools to uncover and evaluate local hazard expectations, posing questions such as the following: How is the population historically situated relative to the uncertainty of the hazards to which it is exposed? What temporal references are commonly reproduced to make sense of this hazard history? How well is the population informed about the impact of changing landscape conditions on flood patterns? How well do engineering and planning documents communicate to the public the uncertainty of the recurrence intervals involved? Active management of temporal resilience can be motivated by explicit preservation, archiving, and dissemination of flood memory and historical data; for example, the placement of historical high-water marks in the landscape or the provision of other visual clues (photographs, descriptions) of past events that provide referential knowledge to newcomers, such as was done in downtown Sacramento (Figs. 4 and 5).

Fig. 4. Public historical ecological education in the City of Sacramento Historic Landmark District, near the riverfront (photo by author).

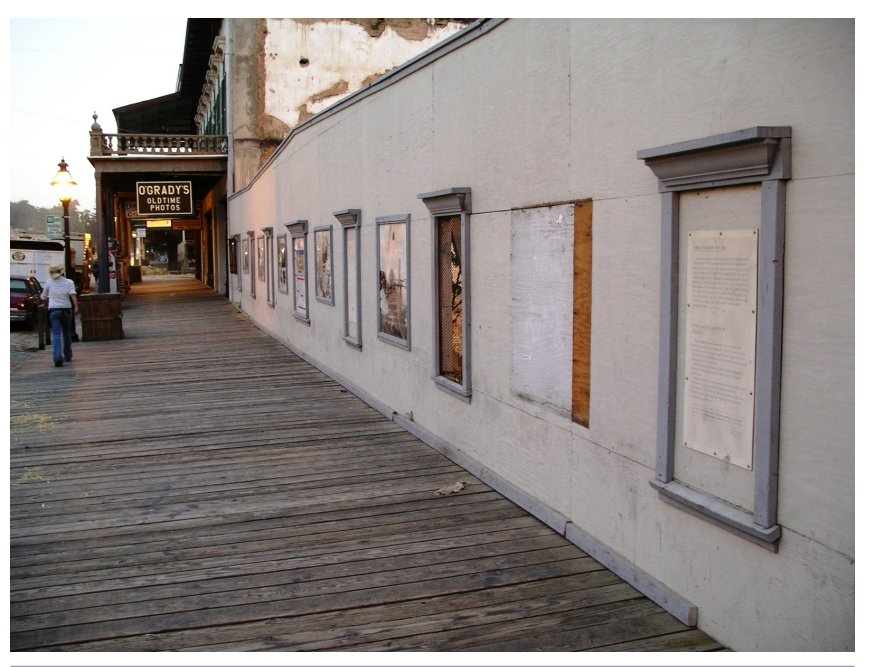

Fig. 5. Public temporal reference to past flood, City of Sacramento Historic Landmark District (photo by author).

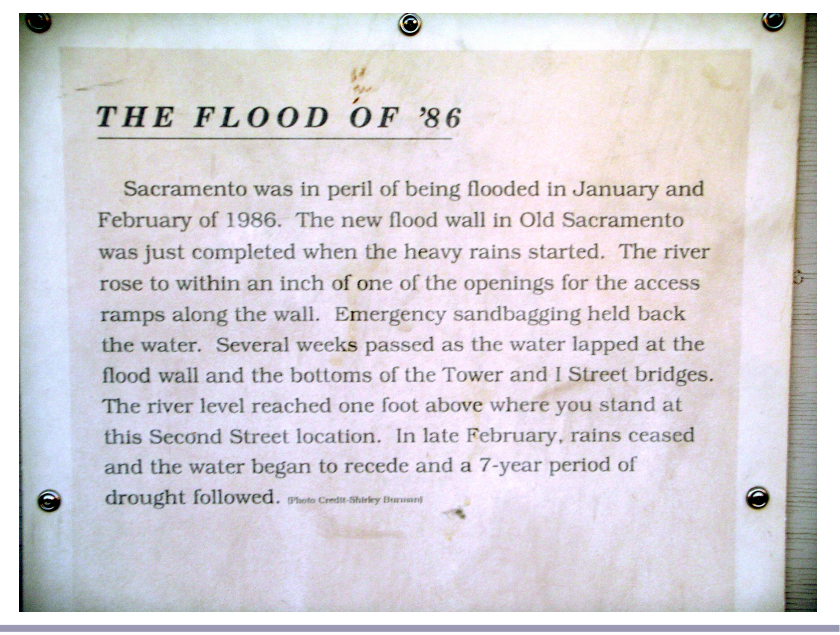


Fig. 6. Temporal vulnerability map, based on temporal distance from proxy baseline flood events.
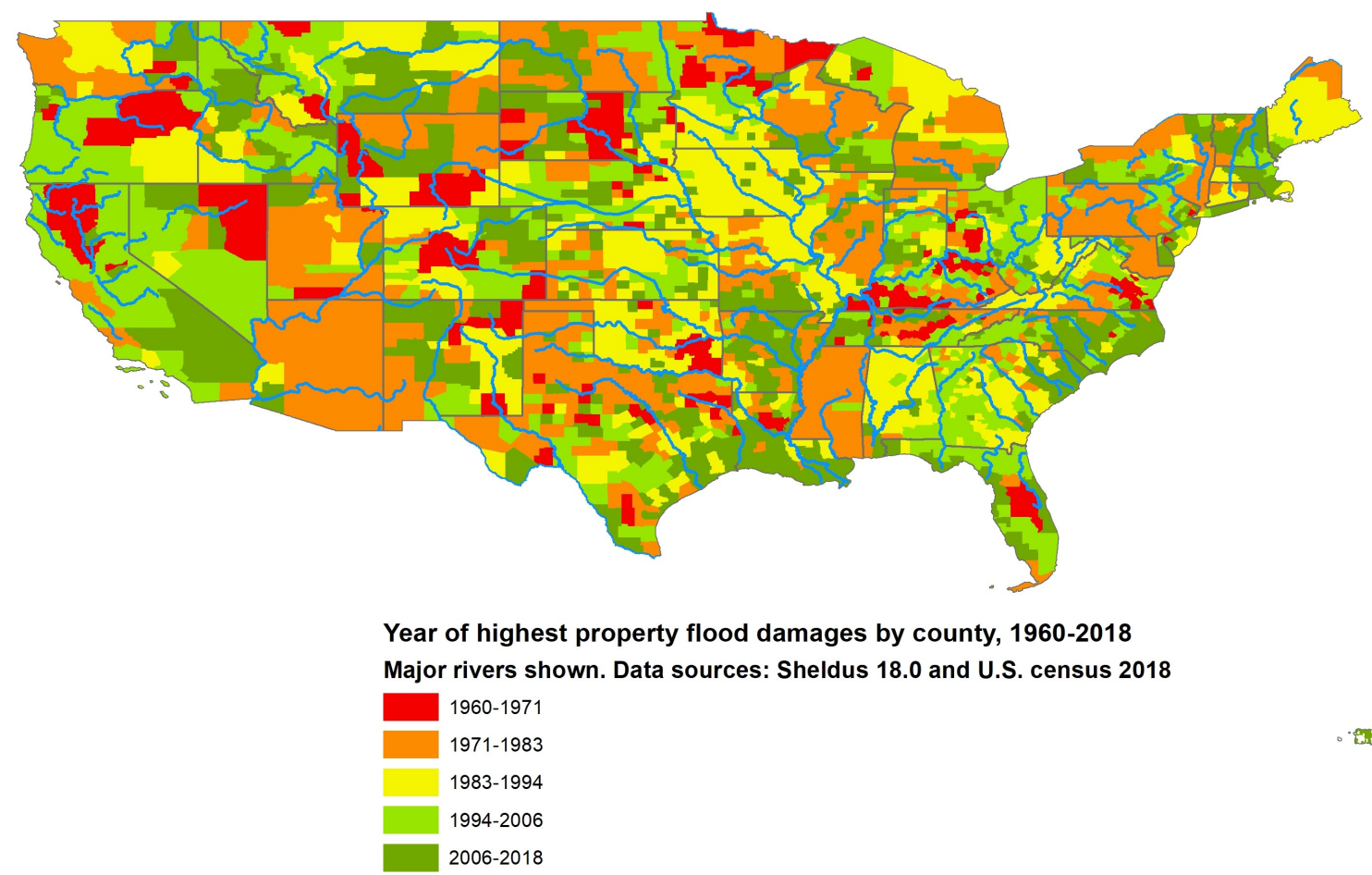

The extent to which such markers are effective on their own may be limited, as for example in modern Japan, where the ancient tsunami stones were largely ignored (Fackler 2011), which exacerbated the brunt of the magnitude 9.0 earthquake and tsunami on March 11, 2011. Such memory projects need to be embedded, therefore, in more elaborate strategies, including a focus on the role of museums and schools in addressing local and regional flood history, support to archival institutions for the preservation of historical flood documentation, or grants to historical societies to engage in neighborhood-level, oral hazard histories.

Further, the development of a metric of temporal vulnerability is badly needed; one that can, for example, map out an index. Fig. 6 shows a simple map that illustrates temporal vulnerability due to increasing temporal distance from the baseline flood event. As a simple example, temporal distance is presumed to place increasing pressure on the quality of memory-networks to remember the impact and even occurrence of such events accurately.

In this case, a simplified proxy measure is taken to represent the baseline flood event, namely the flood event that occurred in the period from 1960 through 2018 and had the highest property damage. I mapped the year in which this event occurred for each U.S. county (with county boundaries dissolved to create a surface) and showed the major river areas. The data were obtained from the SHELDUS database (CEMHS 2018). The result is a map that highlights counties of possible concern with respect to issues of emergency preparedness. In particular, it shows in red the counties that from the perspective of those evaluating flood expectations in 2018 experienced their most damaging flood event almost three to five decades ago, which is an interval subject to generational change. Several of these areas are located right along major rivers and coastal areas.

The results of this study further show that regarding environmental monitoring, capacity development at the level of neighborhood institutions is important. It is at this level that longtime residents anchor past knowledge of events (the flood generation), typically associated with an interest in reducing property turnover and increasing retention. While neighborhood turnover is associated with larger socioeconomic forces, to some extent the decision for disaster generation residents to stay can be motivated by special governmental support to this group and the various neighborhood infrastructures in which they participate (e.g., neighborhood associations, community flood action groups), including training new residents. The general processes and practices of effective community engagement are desirable to achieve this. Similarly, capacity building is important to the institutional management of floodplains, where retention directly helps increase memory of past events. Efforts to increase retention of emergency management officials include a focus on, for example, improving job satisfaction, workload, and/or salaries.

\section{DISCUSSION}

Social learning has increasingly been featured as a key element in avoiding surprises, both in positive and negative ways (Folke et al. 2005, McGlade and Van den Hove 2013, Dilling et al. 2017, Plümper et al. 2017). The findings in this study strongly support this emphasis in the case of floodplain landscapes, and 
deconstruct the complexity of such learning by pointing at interactions that influence such social learning processes. Building on Holling's original emphasis on human expectations relative to perceived reality (Holling 1986, 1995), these findings illustrate how understanding surprise conditions needs more anthropological attention to human meaning-making processes in their interaction with the timing of hazard events and landscape changes. Attention to the quality of human temporal referencemaking practices and memory-networks, and the incorporation of surprise as a temporal vulnerability, provide a novel addition to the existing literature. The proposed temporal vulnerability framework builds upon the notion that vulnerabilities are "processes" and that all vulnerabilities have histories, yet encompasses the idea that temporality itself may be a driver of population vulnerability; an idea rarely addressed (but see Bankoff 2004).

A major objection that is often made against the idea that analysis of temporal vulnerability is worthwhile is that studies of history and memory fail to consider that the shocks and disturbances of the future will be different from those in the past. However, I believe that remaining naive about the quality of temporal reference-making practices seems out of line with precautionary principles. There are at least three counterarguments for this. First, the mere act of social learning about surprise conditions in the past means that anticipation of future surprise becomes more normalized. This awareness will, by itself, reduce temporal vulnerability and may build in a certain "resilience" against even qualitatively different surprises. As Dilling et al. (2017:1) put it:

\section{We argue that surprise is an unavoidable component of weather and climate disasters-one that we must acknowledge, learn to anticipate, and incorporate into risk assessment and management efforts. In sum, although it may seem paradoxical, we should be learning how to expect surprise.}

Knowing one can be surprised - essentially a resilient attitudeis better than thinking "all will be well". Second, the observation that knowledge about history and memory is not relevant for future events misses the central thesis of this paper, which is that surprise by itself is a vulnerability. Surprise is a human experience, and in that sense its occurrence is not entirely dependent on what exactly caused it. Meaning is generated based on the timing of events, on interactions with landscape processes, and on properties inherent to social systems, such as technological optimism. Difference, in other words, is not the unique condition for surprise. Third, knowledge of a hazardscape's surprise conditioning contributes to an understanding of the safe operating space within the current system, and this tentatively means that evaluators can better judge how novel events may exceed known boundaries, even if they are different in quality. Crucial here is reasoning from historical analogs (Crumley 1994) and extrapolation of lessons learned from the past about early warning and adaptive behaviors (Berkes 1999). Perhaps the general failure to acknowledge the role of social memory is the result of uneasiness among scientists, historians, and the public to step beyond the safe boundaries of chronological or linear time. We perceive historical analogs as "out of date," simply irrelevant to the "new" times in which we have arrived, where all conditions are different. As such, the momentum of the past quickly loses its relevance, and what is left of the analysis of historical vulnerability is to find the root causes for the objective changes that have taken place. Yet, when failing to address social time and associated memory-networks, vulnerability models fail to acknowledge the historical situatedness of populations and how their temporal connection to the past influences their expectations relative to perceived reality.

\section{CONCLUSION}

When surprises are seen as historical conditions as opposed to events, avoiding surprises in disaster risk reduction means that the conditions for surprise have to be historically examined (de Vries 2008). A temporal vulnerability assessment does this because collective surprise is uniquely dependent on human expectations rooted in culturally constructed models of historical ecological knowledge. These cultural models are broadly influenced by (1) the quality of references to past experiences and other memory-networks, (2) the speed of landscape transformations, and (3) the random spacing of hazard events in time. In the resulting "surprise ecologies", interactions between these three systems create temporal vulnerability to surprise. Examples of such interactions were thematically presented in this paper using three categories that deal with the quality of temporal reference practices: (1) a lack of temporal references to refer to as a result of structural inabilities to know (ignorance), (2) the erosion of temporal referencing practices, linked to the quality of memory-networks and transitions therein (naivety), and (3) misguided temporal referencing practices often resulting from cognitive dissonance and cultural indifference (denial). While this interpretive framework is only exploratory and preliminary in terms of the review of possible influencing factors, the temporal vulnerability framework and the possibility of deriving resilience measures at a minimum re-emphasizes the importance of introducing anthropological understandings of time, timing, and temporality into effective management of early warning signals and emergency preparedness generally.

Responses to this article can be read online at: http://www.ecologyandsociety.org/issues/responses. $\mathrm{php} / 11274$

\section{Acknowledgments:}

This work was funded in part through small grants by the WennerGren Foundation for Anthropological Research (\#7128), the Public Entity Risk Institute and National Science Foundation, UNCChapel Hill Center for the Study of the American South, and the UNC-Chapel Hill Carolina Population Center. The author expresses his thanks to fieldwork respondents, the anonymous reviewers of previous versions of this paper, Dr. Carole Crumley, Dr. Ben Wisner, and Ms. Catriona Black, and of course Cara Crisler for her ongoing support.

\section{LITERATURE CITED}

Adger, W. N. 2000. Social and ecological resilience: are they related? Progress in Human Geography 24:347-364. https://doi. org/10.1191/030913200701540465 
Alexander, D. 2000. Confronting catastrophe: new perspectives on natural disasters. Oxford University Press, New York, USA.

Bankoff, G. 2004. Time is of the essence: disasters, vulnerability and history. International Journal of Mass Emergencies and Disasters 22:23-42.

Barthel, S., C. Folke, and J. Colding. 2010. Social-ecological memory in urban gardens-retaining the capacity for management of ecosystem services. Global Environmental Change 20:255-265. https://doi.org/10.1016/j.gloenvcha.2010.01.001

Bazerman, M. H., and M. D. Watkins. 2004. Predictable surprises: the disasters you should have seen coming, and how to prevent them. Harvard Business School Press, Boston, Massachusetts, USA.

Berkes, F. 1999. Sacred ecology:traditional ecological knowledge and resource management. Taylor and Francis, Philadelphia, Pennsylvania, USA.

Berkes, F., and C. Folke. 2002. Back to the future: ecosystem dynamics and local knowledge. Pages 121-146 in L. H. Gunderson and C. S. Holling, editors. Panarchy: understanding transformation in human and natural systems. Island Press, Washington, D.C., USA.

Biggs, R., S. R. Carpenter, and W. A. Brock. 2009. Turning back from the brink: detecting an impending regime shift in time to avert it. Proceedings of the National Academy of Sciences of the United States of America 106:826-831. https://doi.org/10.1073/ pnas.0811729106

Blaikie, P., T. Cannon, I. Davis, and B. Wisner. 1994. At risk: natural hazards, people's vulnerability, and disasters. Routledge, London, UK.

Burby, R. J. 2006. Hurricane Katrina and the paradoxes of government disaster policy: bringing about wise governmental decisions for hazardous areas. Annals of the American Academy of Political and Social Science 604:171-191. https://doi. org/10.1177/0002716205284676

Burley, D., P. Jenkins, S. Laska, and D. Traber. 2007. Place attachment and environmental change in coastal Louisiana. Organization \& Environment 20:347-366. https://doi. org/10.1177/1086026607305739

Carpenter, S. R., W. A. Brock, C. Folke, E. H. van Nes, and M. Scheffer. 2015. Allowing variance may enlarge the safe operating space for exploited ecosystems. Proceedings of the National Academy of Sciences of the United States of America 112:14384-14389. https://doi.org/10.1073/pnas.1511804112

Center for Emergency Management and Homeland Security (CEMHS). 2018. Spatial hazard events and losses database for the United States. Arizona State University, Phoenix, Arizona.

Connerton, P. 1989. How societies remember. Cambridge University Press, Cambridge. https://doi.org/10.1017/CBO9780511628061

Connor, E. 2016. Hurricane Matthew damage in Savannah not as bad as feared. The Greenville (S.C.) News.

Cooper, M. D. 2000. Towards a model of safety culture. Safety Science 36:111-136. https://doi.org/10.1016/S0925-7535(00)00035-7
Crumley, C. L. 1994. Historical ecology: cultural knowledge and changing landscapes. School of American Research, Santa Fe, New Mexico, USA.

Crumley, C. L. 2002. Exploring venues of social memory. Pages 39-52 in J. J. Climo and M. G. Cattell, editors. Social memory and history: anthropological perspectives. Bergin \& Garvey, New York, USA.

Cutter, S. L. 1996. Vulnerability to environmental hazards. Progress in Human Geography 20:529-539. https://doi. org/10.1177/030913259602000407

Davis, T., H. Rogers, C. Shays, H. Bonilla, S. Buyer, S. Myrick, M. Thornberry, K. Granger, C. W. Pickering, B. Shuster, and J. Miller. 2006. A failure of initiative: the final report of the Select Bipartisan Committee to Investigate the Preparation for and Response to Hurricane Katrina. U.S. House of Representatives, Washington D.C., USA.

de Vries, D. H. 2007. Being temporal and vulnerability to natural disasters. Pages 36-49 in K. Warner, editor. Perspectives on social vulnerability. United Nations University Press, Bonn, Germany.

de Vries, D. H. 2008. Temporal vulnerability: historical ecologies of monitoring, memory, and meaning in changing United States floodplain landscapes. Proquest, Ann-Arbor, Michigan, USA.

de Vries, D. H. 2011a. Temporal vulnerability in hazardscapes: flood memory-networks and referentiality along the North Carolina Neuse River (USA). Global Environmental Change 21:154-164. https://doi.org/10.1016/j.gloenvcha.2010.09.006

de Vries, D. H. 2011b. Social time and population vulnerability to natural hazards. Pages 140-160 in H. Kopnina and E. Shoreman-Ouimet, editors. Environmental anthropology today. Routledge, London, UK.

de Vries, D. H. 2017. Temporal vulnerability and the post-disaster 'Window of Opportunity to Woo:' a case study of an AfricanAmerican floodplain neighborhood after Hurricane Floyd in North Carolina. Human Ecology 45:437-448. https://doi. org/10.1007/s10745-017-9915-4

de Vries, D. H., and J. Fraser. 2012. Citizenship rights and voluntary decision making in post-disaster U.S. floodplain buyout mitigation programs. International Journal of Mass Emergencies and Disasters 30:1-33.

Dilling, L., R. Morss, and O. Wilhelmi. 2017. Learning to expect surprise: Hurricanes Harvey, Irma, Maria, and beyond. Journal of Extreme Events 4:1-8. https://doi.org/10.1142/S2345737617710014

Douglas, M., and A. Wildavsky. 1983. Risk and culture: an essay on the selection of technological and environmental dangers. University of California Press, London, UK.

Duijm, N. J. 2009. Safety-barrier diagrams as a safety management tool. Reliability Engineering \& Systems Safety 94:332-341. https://doi.org/10.1016/j.ress.2008.03.031

Erikson, K. 1994. A new species of trouble: explorations in disaster, trauma and community. W. W. Norton \& Company, New York, USA.

European Environment Agency. 2001. Late lessons from early warnings: the precautionary principle 1986-2000. Report on 
Environmental Issues Report No 22. European Environment Agency, Luxembourg.

Fackler, M. 2011. Tsunami warnings, written in stone. The New York Times, April 20, 2011. https://www.nytimes.com/2011/04/21/ world/asia/21stones.html

Festinger, L. 1957. A theory of cognitive dissonance. Stanford University Press, Stanford, California, USA.

Folke, C. 2006. Resilience: the emergence of a perspective for social-ecological systems analyses. Global Environmental Change 16:253-267. https://doi.org/10.1016/j.gloenvcha.2006.04.002

Folke, C., S. Carpenter, B. Walker, M. Scheffer, T. Elmqvist, L. Gunderson, and C. S. Holling. 2004. Regime shifts, resilience, and biodiversity in ecosystem management. Annual Review of Ecology, Evolution, and Systematics 35:557-581. https://doi. org/10.1146/annurev.ecolsys.35.021103.105711

Folke, C., T. Hahn, P. Olsson, and J. Norberg. 2005. Adaptive governance of social-ecological systems. Annual Review of Environment and Resources 30:441-473. https://doi.org/10.1146/ annurev.energy.30.050504.144511

Forrest, T. R. 1993. Disaster anniversary: a social reconstruction of time. Sociological Inquiry 63:444-456. https://doi.org/10.1111/ j.1475-682X.1993.tb00323.X

Fraser, J., D. H. de Vries, and H. Young. 2005. Creating the enabling conditions for mitigation repetitive loss properties. University of North Carolina, Center for Urban and Regional Studies, Chapel Hill, North Carolina, USA.

Freier, N. 2008. Known unknowns: unconventional "strategic shocks" in defense strategy development. Strategic Studies Institute, Washington D.C., USA.

Funtowicz, S. O., and J. R. Ravetz. 1993. Science for the postnormal age. Futures 25:739-755. https://doi.org/10.1016/0016-3287 (93)90022-L

Glaser, B. G., and A. L. Strauss. 1967. Discovery of grounded theory: strategies for qualitative research. Aldine, Chicago, Illinois, USA. https://doi.org/10.4324/9780203793206

Gordon, L. J., G. D. Peterson, and E. M. Bennett. 2008. Agricultural modifications of hydrological flows create ecological surprises. Trends in Ecology \& Evolution 23:211-219. https://doi. org/10.1016/j.tree.2007.11.011

Guckenheimer, J., and P. Holmes. 1983. Nonlinear oscillations, dynamical systems, and bifurcations of vector fields. SpringerVerlag, New York, USA. https://doi.org/10.1007/978-1-4612-1140-2

Gunderson, L. H. 2004. Adaptive dancing: interactions between social resilience and ecological crises. Pages 33-52 in F. Berkes, J. Colding, and C. Folke, editors. Navigating social-ecological systems: building resilience for complexity and change. Cambridge University Press, Cambridge. https://doi.org/10.1017/ CBO9780511541957.005

Gunderson, L. H. 2010. Ecological and human community resilience in response to natural disasters. Ecology and Society 15 (2):18. https://doi.org/10.5751/ES-03381-150218

Halbwachs, M. 1992. On collective memory. University of Chicago Press, Chicago, Illinois, USA.
Hecht, J. 1990. The incredible shrinking Mississippi Delta. New Scientist, April 14, 1990.

Hendrickx, L., A. Van den Berg, and C. Vlek. 1993. Concern about tomorrow? The factor 'time' in the evaluation of environmental risks. Milieu, Tijdschrift voor Milieukunde 8:146-152.

Hoffman, S. M., and A. O. Oliver-Smith. 2002. Culture and catastrophe: the anthropology of disaster. School of American Research Press, Santa Fe, New Mexico, USA.

Holland, D. C., and N. Quinn. 1987. Cultural models in language and thought. Cambridge University Press, London, UK. https:// doi.org/10.1017/CBO9780511607660

Holling, C. S. 1973. Resilience and stability of ecological systems. Annual Review of Ecology and Systematics 4:1-23. https://doi. org/10.1146/annurev.es.04.110173.000245

Holling, C. S. 1986. The resilience of terrestrial ecosystems: local surprise and global change. Pages 292-317 in W. C. Clark and R. E. Munn, editors. Sustainable development of one biosphere. Cambridge University Press, Cambridge.

Holling, C. S. 1995. What barriers? What bridges? Pages 16-36 in L. Gunderson, C. S. Holling, and S. S. Light, editors. Barriers and bridges to the renewal of ecosystems and institutions. Columbia University Press, New York, USA.

Holling, C. S., and L. H. Gunderson. 2002. Resilience and adaptive cycles. Pages 52-62 in L. H. Gunderson and C. S. Holling, editors. Panarchy: understanding transformations in human and ecological systems. Island Press, Washington, D.C., USA.

Ingold, T. 1993. The temporality of the landscape. World Archaeology 25:152-174. https://doi.org/10.1080/00438243.1993.9980235

Intergovernmental Panel on Climate Change (IPCC). 2007. Appendix 1: Glossary. Pages 869-883 in M. Parry, O. Canziani, J. Palutikof, P. Van der Linden, and C. Hanson, editors. Climate change 2007: impacts, adaptation and vulnerability. Contribution of Working Group II to the Fourth Assessment Report of the Intergovernmental Panel on Climate Change, Cambridge University Press, Cambridge.

Irons, L. 2005. Hurricane Katrina as a predictable surprise. Homeland Security Affairs I, Article 7. https://www.hsaj.org/ articles/690

Kates, R. W., and W. C. Clark. 1996. Environmental surprise: expecting the unexpected? Environment 38:6-34. https://doi. org/10.1080/00139157.1996.9933458

Kates, R. W., C. E. Colten, S. Lask, and S. P. Leatherman. 2006. Reconstruction of New Orleans after Hurricane Katrina: a research perspective. Proceedings of the National Academy of Sciences 103:14653-14660. https://doi.org/10.1073/pnas.0605726103

Klein, N. 2005. 'Never before!' Our amnesiac torture debate. The Nation, December 26, 2005.

Klein, N. 2007. The shock doctrine: the rise of disaster capitalism. Metropolitan Books, Richmond, British Columbia, Canada.

Latour, B. 1988. Science in action: how to follow scientists and engineers through society. Harvard University Press, Cambridge, Massachusetts, USA. 
Latour, B. 1999. Circulating reference: sampling the soil in the Amazon forest. Pages 24-79 in B. Latour, editor. Pandora's hope: essays on the reality of science studies. Harvard University Press, Cambridge, Massachusetts, USA.

Leavitt, W. M., and J. J. Kiefer. 2006. Infrastructure interdependency and the creation of a normal disaster: the case of Hurricane Katrina and the City of New Orleans. Public Works Management \& Policy 10:306. https://doi.org/10.1177/1087724X06289055

Leslie, P., and J. T. McCabe. 2013. Response diversity and resilience in social-ecological systems. Current Anthropology 54:114-143. https://doi.org/10.1086/669563

Ludwig, D., B. Walker, and C. S. Holling. 1997. Sustainability, stability, and resilience. Conservation Ecology 1(1):7. https://doi. org/10.5751/ES-00012-010107

McCoy, M. B. 2013. Wounded heroes: vulnerability as a virtue in ancient Greek literature and philosophy. Oxford University Press, New York, USA. https://doi.org/10.1093/acprof: oso/9780199672783.001.0001

McDaniel, R. R., and D. J. Driebe. 2005. Uncertainty and surprise: ideas from the open discussion. Pages 183-200 in R. R. $\mathrm{McDaniel}$ and D. Driebe, editors. Uncertainty and surprise in complex systems: questions on working with the unexpected. Springer-Verlag Berlin, Heidelberg, Germany. https://doi. org/10.1007/b13122

McGlade, J., and S. Van den Hove. 2013. Ecosystems and managing the dynamics of change. Pages 407-428 in D. Gee, P. Grandjean, S. Foss Hansen, S. Van den Hove, M. MacGarvin, J. Martin, G. Nielsen, D. Quist, and D. Stanners, editors. Late lessons from early warnings: science, precaution, innovation. European Environment Agency, Copenhagen, Denmark.

Morton, R. A., N. A. Buster, and M. D. Krohn. 2002. Subsurface controls on historical subsidence rates and associated wetland loss in southcentral Louisiana. Transactions Gulf Coast Association of Geological Societies 52:767-778.

Munn, N. D. 1992. The cultural anthropology of time: a critical essay. Annual Review of Anthropology 21:93-123. https://doi. org/10.1146/annurev.an.21.100192.000521

National Research Council. 2006. Facing hazards and disasters: understanding human dimensions. National Academies Press, Washington, D.C., USA.

Nelson, C., N. Lurie, and J. Wasserman. 2007. Conceptualizing and defining public health emergency preparedness. American Journal of Public Health 97:S9-11. https://doi.org/10.2105/ AJPH.2007.114496

Nicolis, G., and I. Prigogine. 1989. Complexity in nature. In G. Nicolis and I. Prigogine, editors. Exploring complexity: an introduction. W. Freeman and Company, New York, USA.

Niemeyer, S., J. Petts, and K. Hobson. 2005. Rapid climate change and society: assessing responses and thresholds. Risk Analysis 25:1443-1456. https://doi.org/10.1111/j.1539-6924.2005.00691.x

Nora, P. 1989. Between memory and history: les lieux de memoire. Representations 26:7-25.
Núñez, R., and E. Sweetser. 2006. With the future behind them: convergent evidence from Aymara language and gesture in the crosslinguistic comparison of spatial construals of time. Cognitive Science 30:401-450. https://doi.org/10.1207/s15516709cog0000_62

Oliver-Smith, A. 2012. Haiti's 500-year earthquake. Pages 18-23 in M. Schuller and P. Morales, editors. Tectonic shifts: Haiti since the earthquake. Kumarian Press, Sterling.

Oliver-Smith, A., I. Alcántara-Ayala, I. Burton, and A. Lavell. 2016. Forensic investigations of disasters: a conceptual framework and guide to research. Integrated Research on Disaster Risk (IRDR), Beijing, China.

Omer, H., and N. Alon. 1994. The continuity principle: a unified approach to disaster and trauma. American Journal of Community Psychology 22:273-287. https://doi.org/10.1007/BF02506866

Parsons, T. 1937. The structure of social action. A study in social theory with special reference to a group of recent European writers. McGraw Hill, New York, USA.

Perrow, C. 1999. Normal accidents: living with high risk technologies. Princeton University Press, Princeton, New Jersey, USA.

Plümper, T., A. Quiroz Flores, and E. Neumayer. 2017. The double-edged sword of learning from disasters: mortality in the Tohoku tsunami. Global Environmental Change 44:49-56. https:// doi.org/10.1016/j.gloenvcha.2017.03.002

Schneider, S. H., S. Semenov, A. Patwardhan, I. Burton, C. H. D. Magadza, M. Oppenheimer, A. B. Pittock, A. Rahman, J. B. Smith, A. Suarez, and F. Yamin. 2007. Assessing key vulnerabilities and the risk from climate change. Pages 779-810 in M. L. Parry, O. F. Canziani, J. P. Palutikof, P. J. Van der Linden, and C. E. Hanson, editors. Climate change 2007: impacts, adaptation and vulnerability. Contribution of Working Group II to the Fourth Assessment Report of the Intergovernmental Panel on Climate Change. Cambridge University Press, Cambridge.

Schneider, S. H., and B. L. Turner. 1994. Surprise and global environmental change. Aspen Global Change Institute, Basalt, Colorado, USA.

Schwartz, P., and D. Randall. 2007. Ahead of the curve: anticipating strategic surprise. Pages 93-108 in F. Fukuyama, editor. Blindside: how to anticipate forcing events and wild cards in global politics. Brookings Institution Press, Washington, D.C., USA.

Sims, B. 2007. 'The day after the hurricane': infrastructure, order, and the New Orleans Police Department's response to Hurricane Katrina. Social Studies of Science 37:111. https://doi. org/10.1177/0306312706069432

Taleb, N. N. 2007. The Black Swan: the impact of the highly improbable. Penguin, London, UK.

Thompson, M., R. Ellis, and A. Wildavsky. 1990. Cultural theory. West View Press, Oxford. https://doi.org/10.4324/9780429501180

Tidwell, M. 2003. Bayou farewell: the rich life and tragic death of Louisiana's Cajun coast. Vintage Books, New York, USA. 
Tolich, M., and K. Baldwin. 2005. Informing consent in New Zealand research: researcher's conflict of interest and patient vulnerability. New Zealand Medical Journal 118:1-8.

Tversky, A., and D. Kahneman. 1987. Judgment under uncertainty: heuristics and biases. Cambridge University Press, Cambridge. https://doi.org/10.21236/AD0767426

Wade-Benzoni, K. A. 1999. Thinking about the future: an intergenerational perspective on the conflict and compatibility between economic and environmental interests. American Behavioral Scientist 42:1393-1405. https://doi.org/10.1177/0002$\underline{7649921954912}$

Walker, B., and D. Salt. 2006. Resilience thinking: sustaining ecosystems and people in a changing world. Island Press, Washington, D.C., USA.

Wallace, A. 1957. Mazeway disintegration: the individual's perception of socio-cultural disorganization. Human Organization 16:23-27. https://doi.org/10.17730/humo.16.2.pt214314t767kr3w

Weber, M. 1978. Economy and society: an outline of interpretive sociology. University of California Press, Oakland, California, USA.

Weick, K. E., and K. M. Sutcliffe. 2001. Managing the unexpected: assuring high performance in an age of complexity. Jossey-Bass, San Francisco, California, USA.

West, J. R. 1987. Fetal alcohol-induced brain damage and the problem of determining temporal vulnerability: a review. Alcohol and Drug Research 7:423-441.

Westley, F., P. Olsson, C. Folke, T. Homer-Dixon, and H. Vredenburg et al. 2011. Tipping toward sustainability: emerging pathways of transformation. Ambio 40:762-780. https://doi. org/10.1007/s13280-011-0186-9

Wisner, B. 2016. Vulnerability as concept, model, metric, and tool. Pages 1-58 in S. L. Cutter, editor. Oxford research encyclopedia, natural hazard science. Oxford University Press, Oxford, UK. https://doi.org/10.1093/acrefore/9780199389407.013.25

Wisner, B., J. C. Gaillard, and I. Kelman. 2012. Framing disaster: theories and stories seeking to understand hazards, vulnerability and risk. Pages 15-33 in B. Wisner, J. C. Gaillard, and I. Kelman, editors. Handbook of hazards and disaster risk reduction. Routledge, London, UK.

Yudkowsky, E. 2011. Cognitive biases potentially affecting judgment of global risks. Pages 91-119 in N. Bostrom and M. Cirkovic, editors. Global Catastrophic Risks. Oxford University Press, New York, USA.

Zerubavel, E. 2003. Time maps: collective memory and the social shape of the past. University of Chicago Press, Chicago, Illinois, USA. 